\title{
IMPOSTO SOBRE GRANDES FORTUNAS E FUNDO DE COMBATE E ERRADICAÇÃO DA POBREZA: COMPETÊNCIA TRIBUTÁRIA, OMISSÃO INCONSTITUCIONAL E VIOLAÇÃO DE DIREITOS FUNDAMENTAIS
}

\author{
WEALTH TAX AND COMBAT \\ AND ERADICATION OF POVERTY FUND: \\ TAX COMPETENCE, UNCONSTITUTIONAL OMISSION \\ AND VIOLATION OF FUNDAMENTAL RIGHTS
}

\author{
JULIA PIRES PEIXOTO DOS SANTOS ${ }^{1}$ \\ MARIO DI STEFANO FILHO ${ }^{2}$ \\ VINÍCIUS GOMES CASALINO ${ }^{3}$
}

\section{RESUMO}

O presente artigo trata do Imposto sobre Grandes Fortunas (IGF), o qual, apesar de previsto no artigo 153, inciso VII, da Constituição Federal de 1988, ainda não foi implementado, carecendo de regulamentação por lei complementar. Nessa linha, o trabalho tem como objetivo promover uma análise crítica acerca da não instituição do IGF frente ao cenário de desigualdade brasileiro. Assim, a partir de um exame amplo do con-

1 Graduanda em Direito na Universidade Pontifícia Universidade Católica de Campinas. Bolsista no programa de Iniciação Científica da PUC-Campinas, com o tema "Políticas Públicas e Políticas Tributárias", na modalidade FAPIC/Reitoria, sob a orientação do professor-pesquisador Dr. Vinícius Gomes Casalino. ORCID iD: https://orcid.org/0000-0001-7506-2378. E-mail: juliapirespeixoto@gmail.com.

2 Mestrando no Programa de Pós-Graduação de Direito (PPGD) da Pontifícia Universidade Católica de Campinas, Bolsista CAPES/PROSUC com dedicação exclusiva, vinculado à linha de pesquisa Direitos Humanos e Políticas Públicas. Pós-graduado em Direito Tributário pela Pontifícia Universidade Católica de Campinas e pós-graduado em Direito Público pela FACAB. Bacharel em Direito pela Pontifícia Universidade Católica de Campinas. ORCID iD: https://orcid.org/0000-00022429-8345. E-mail: mariodsfilho.adv@gmail.com.

3 Professor titular (categoria A1) da Faculdade de Direito da Pontifícia Universidade Católica de Campinas (PUCCAMP) em regime de tempo integral e dedicação exclusiva. Orientador de mestrado, está vinculado à linha de pesquisa Direitos Humanos e Políticas Públicas do Programa de Mestrado em Direitos Humanos e Desenvolvimento Social. Pós-Doutor pelo Departamento de Economia da Faculdade de Economia, Administração e Contabilidade da Universidade de São Paulo (FEA-USP). Doutor e Mestre pelo Departamento de Filosofia e Teoria Geral do Direito da Faculdade de Direito da Universidade de São Paulo (Largo São Francisco-USP), instituição pela qual obteve o grau de bacharel em direito. Pós-doutorado em andamento pelo Departamento de História da Faculdade de Filosofia, Letras e Ciências Humanas da Universidade de São Paulo (FFLCH-USP). ORCID iD: https://orcid.org/0000-0003-0003-3315. E-mail: vinicius.casalino@puc-campinas.edu.br.

Como citar esse artigo/How to cite this article:

SANTOS, Julia Pires Peixoto dos; STEFANO FILHO, Mario Di; CASALINO, Vinícius Gomes. Imposto sobre grandes fortunas e fundo de combate e erradicação da pobreza: competência tributária, omissão inconstitucional e violação de direitos fundamentais. Revista Meritum, Belo Horizonte, vol. 15, n. 4, p. 172-195, 2020. DOI: https://doi.org/ 10.46560/meritum.v15i4.8153. 
teúdo e da natureza vinculante dos objetivos constitucionalmente definidos, dentre eles a erradicação da pobreza e a redução das desigualdades (artigo $3^{\circ}$, inciso III, CF), e do papel da atividade legislativa tributária na sua concretização, o estudo procura responder ao seguinte problema de pesquisa: na medida em que a Constituição vincula expressamente as receitas oriundas da arrecadação do IGF ao financiamento do Fundo de Combate e Erradicação da Pobreza, instrumento típico de implementação de políticas públicas voltadas à promoção de direitos fundamentais sociais, a Constituição não estaria determinando explicitamente o exercício da competência tributária? Nesse sentido, levanta-se a hipótese de que o legislador federal incorre em omissão inconstitucional ao não editar a norma infraconstitucional regulamentadora, dada a sua indispensabilidade para o adequado custeio do fundo, crucial para atingir os objetivos fundamentais da República. Para exame do proposto, optou-se pelo método hipotético-dedutivo, com análise e interpretação de dados, nacionais e estrangeiros, juntamente com pesquisa bibliográfica de artigos qualificados sobre o assunto e instrumentos legislativos pertinentes. Conclui-se, por conseguinte, pela necessidade de se revisitar o paradigma da facultatividade como atributo da competência tributária, defendido de forma quase unânime pela doutrina de direito público, e, assim, averiguar se o não exercício da atividade tributária legislativa pelo ente tributante viola mandamento constitucional expresso, buscando, em caso afirmativo, compreender que consequências jurídicas podem ser daí extraídas.

Palavras-chave: Imposto sobre Grandes Fortunas. Fundo de Combate e Erradicação da Pobreza; Direitos fundamentais sociais. Competência tributária. Inconstitucionalidade por omissão.

\section{ABSTRACT}

The present article deals with the Wealth Tax, which, although established in article 153, subparagraph VII, of the 1988 Federal Constitution, has not yet been implemented, lacking regulation by complementary law. In this regard, the paper has as its objective to promote a critical analysis about the non-institution of the Wealth Tax in face of the Brazilian inequality scenario. Thus, from a broad examination of the content and binding nature of the constitutionally defined objectives, among them the eradication of poverty and the reduction of inequalities (article 3, subparagraph III, Federal Constitution), and the role of tax legislative activity in its concretization, the study seeks to answer the following research problem: insofar as it expressly links the revenues from the collection of the Wealth Tax to the financing of the Combat and Eradication of Poverty Fund, a typical instrument for implementing public policies aimed at the promotion of fundamental social rights, wouldn't the Constitution be explicitly determining the exercise of tax competence? In this sense, the hypothesis is raised that the federal legislator incurs in an unconstitutional omission by not editing the infraconstitucional regulatory rule, given its indispensability for the adequate financing of the fund, crucial to achieve the fundamental objectives of the Republic. To the examination of what proposed, the hypothetical-deductive method was chosen, with data analysis and interpretation from national and foreign sources, together with a bibliographic search of qualified articles on the subject and relevant legislative instruments. It is concluded, there for, the need to revisit the faculty paradigm as an attribute of tax competence, defended almost unanimously by the doctrine of public law, and, thus, ascertain as to whether the non-exercise of legislative tax activity by the taxing entity violates express constitutional commandment, seeking, if so, to comprehend what legal consequences can be drawn from it.

Keywords: Wealth Tax. Combat and Eradication of Poverty Fund. Fundamental social rights. Tax competence. Unconstitutionality by omission.

\section{INTRODUÇÃO}

Sabe-se que a Constituição Federal de 1988, em seu art. $3^{\circ}$, inciso III, consagra como objetivo fundamental da República a erradicação da pobreza e a redução das desigualdades sociais (BRASIL, 1988). Trata-se de um dos fins mais caros à sociedade brasileira, tendo em 
vista a miséria multidimensional e o fenômeno de concentração de riqueza, que permeiam a história do país.

Diante desse contexto, importa analisar a situação do Imposto sobre Grandes Fortunas (IGF), como tributo vinculado constitucionalmente a financiar, com a integralidade do produto de sua arrecadação, o Fundo de Combate e Erradicação da Pobreza, nos termos do que determina o art. 80, III, do ADCT (BRASIL, 1988). Tendo como finalidade precípua subsidiar políticas públicas voltadas à promoção de direitos fundamentais sociais básicos, tais como a saúde e a educação, esse fundo tem nítida vocação para a realização dos fins constitucionais em voga.

Ocorre que, apesar de arrolado no art. 153, VII, da Constituição (BRASIL, 1988), o Imposto sobre Grandes Fortunas, passados mais de 30 anos da promulgação daquela, ainda não foi implementado, dada a inércia do legislativo federal em editar a necessária lei complementar regulamentadora. Em virtude disso, o fundo remanesce em uma situação de evidente subfinanciamento, ficando parcialmente comprometidos, daí, todos os programas suplementares pelos quais se responsabilizou a amparar.

Assim, o presente artigo tem por escopo analisar se o legislador federal incorre em omissão inconstitucional ao não instituir o imposto e, consequentemente, destinar os recursos constitucionalmente vinculados ao financiamento do Fundo.

Para tanto, optou-se pelo método hipotético-dedutivo, valendo-se de pesquisa bibliográfica de obras e artigos científicos pertinentes, assim como instrumentos legislativos que giram em torno da experiência com a taxação de riqueza e diretrizes do Fundo de Combate e Erradicação da Pobreza, além de normas constitucionais que definem e legitimam a prerrogativa estatal.

A fim de se compreender as raízes da reflexão proposta, no capítulo 01 são perquiridos o conteúdo e a natureza vinculante dos fins e objetivos da Constituição bem como o papel do Estado frente a eles. A partir disso, busca-se expor a relação necessária entre a atividade legislativa tributária e a efetivação do programa constitucional.

No capítulo 02, é realizada uma breve análise da figura do Imposto sobre Grandes Fortunas e do Fundo de Combate e Erradicação da Pobreza, averiguando-se tanto a importância de cada instituto isoladamente, como a indispensabilidade da relação de vínculo entre ambos.

Por sua vez, o capítulo 03 busca demonstrar, enfim, a omissão inconstitucional na postura do órgão legiferante ao não instituir o IGF. Para tanto, analisa a (in)compatibilidade da facultatividade como atributo intrínseco à competência tributária, frequentemente utilizada como artifício para mascarar a não instituição do tributo.

Com isso, é possível concluir que, quer em razão do seu excepcional potencial redistributivo, quer em razão da destinação social de suas receitas, a imposição desse tributo tem plena capacidade de atuar positivamente sobre a realidade brasileira. Sendo imprescindível para o triunfo da sua dimensão protetiva, e estando vinculado expressamente ao financiamento de despesas específicas, a Constituição veda que o ente disponha (no sentido de decidir discricionariamente) da sua competência para instituir o IGF, motivo pelo qual urge a sua regulamentação por meio de lei complementar, a cargo do legislador federal.

Por fim, cabe dizer que, tendo sido reinserido no foco de atenção da população brasileira com a deflagração da pandemia do coronavírus no ano de 2020, a qual escancarou as desi- 
gualdades sociais e econômicas do nosso país, a discussão sobre a necessidade de implementação do Imposto sobre Grandes Fortunas é, mais do que nunca, de extrema pertinência.

\section{A ERRADICAÇÃO DA POBREZA E DAS DESIGUALDADES COMO PROJETO CONSTITUCIONAL VINCULANTE DA ATIVIDADE LEGISLATIVA TRIBUTÁRIA}

Como documento jurídico dotado de supremacia formal e material, a Constituição de 1988 revela-se não somente como vetor de interpretação de toda ordem jurídica, mas também como estrutura normativa conformadora da realidade econômica, política e social. Mais do que erigir o Estado de forma meramente abstrata e teórica, portanto, atuando como mero instrumento de governo, esse modelo de Constituição, de índole dirigente, busca se afirmar como um programa de ação comprometido com a efetiva transformação da sociedade pelo direito (CANOTILHO, 2001, p. 6).

Nesse sentido, Hesse (1991, p. 14-15, 24) sustenta que a Constituição jurídica é determinada pela realidade social, ao mesmo tempo em que é determinante em relação a ela. É dizer que, de fato, a pretensão de eficácia da norma jurídica pressupõe a consideração das condições históricas de sua realização, na medida em que a situação por ela regulada pretende ser concretizada em tal realidade. Entretanto, não se limita a ser apenas uma expressão dessas condições, tendo em vista que, graças ao seu elemento normativo, converte-se em força ativa, logrando conferir forma e modificação à conjuntura econômica, política e social corrente.

Com efeito, basta uma simples leitura da Constituição para perceber que o constituinte, ao definir o espectro de valores e as opções políticas orientadoras de toda ordem constitucional e jurídica, de fato considerou a realidade na qual se inseria, isto é, uma sociedade marcada historicamente pela pobreza, por imensas disparidades econômicas e sociais e pela extrema concentração de renda e de patrimônio no topo da pirâmide social. Um país, afinal, que exclui grande contingente da sua população do acesso a condições mínimas necessárias a uma vida digna.

Aliás, o cenário atual brasileiro sequer é muito mais animador em comparação àquele enfrentado pelo constituinte quando da elaboração da Carta Constitucional vigente. Confirmando a tendência das últimas décadas, o crescimento econômico do país não tem sido acompanhado de resultados satisfatórios na redução dos índices de desigualdades de renda e riqueza, tendo sido constatado, no início de 2017, mais de 16 milhões de pessoas vivendo abaixo da linha da pobreza, segundo relatório publicado pela ONG Oxfam Brasil (2017, p. 21). Outrossim, o mesmo relatório também alertava para a extraordinária concentração de riqueza no país, com o $1 \%$ mais rico da população brasileira concentrando $48 \%$ de toda a riqueza nacional, enquanto os $10 \%$ mais ricos ficavam com o impressionante percentual de 74\% (OXFAM BRASIL, 2017, p. 30).

Explicita-se, pois, até os dias de hoje, uma sociedade acentuadamente desigual, sobre a qual a Constituição de 1988 assume o compromisso de atuar no sentido do aprimoramento 
das estruturas econômicas e político-sociais que contribuem para a perpetuação do atraso e das privações decorrentes da insuficiência de renda, vinculando toda atividade estatal à persecução de tal objetivo.

Essa perspectiva fica especialmente clara com o artigo $3^{\circ}$ da Constituição Federal, o qual, como bem pontua Bello, Bercovici e Lima (2019, p. 1771-1772), incorpora um programa de transformações econômicas e sociais como fins jurídicos a serem necessariamente realizados pelo Estado brasileiro. Dentre tais fins, merece destaque, para o propósito do presente artigo, o estabelecimento da construção de uma sociedade livre, justa e solidária e da erradicação da pobreza e da marginalização e da redução das desigualdades sociais e regionais como objetivos basilares da República Federativa do Brasil, este último se desdobrando, inclusive, em vários outros dispositivos constitucionais (v. g., arts. 23, X; 43; 165, § $7^{\circ} ; 170, \mathrm{CF}$ ).

Eros Roberto Grau transmite a mesma ideia ao lembrar:

O enunciado do princípio expressa, de uma banda, o reconhecimento explícito de marcas que caracterizam a realidade nacional: pobreza, marginalização e desigualdades, sociais e regionais. Eis um quadro de subdesenvolvimento, incontestado, que, todavia, se pretende reverter. [...] Dir-se-á que a Constituição, aí nada mais postula, no seu caráter de Constituição, dirigente, senão rompimento do processo de desenvolvimento no qual estamos imersos e, em cujo bojo, pobreza, marginalização e desigualdades, sociais e regionais, atuam em regime de causação circular acumulativa - são causas e efeitos de si próprias (GRAU,2010, p. 220).

Diante de tal contexto, rompe-se com a ideia de que o programa constitucional voltado ao combate da pobreza e da marginalização no país seria apenas um ideal retórico do constituinte, desprovido, pois, de qualquer vinculatividade jurídica, apesar de assim ter sido considerado nos últimos 32 anos. À medida em que o constituinte originário traça fins a serem perseguidos e incorpora-os na qualidade de normas jurídicas cogentes, torna-se indispensável o desenvolvimento de uma dogmática específica capaz de conferir-lhes eficácia (BARCELLOS, 2005, p. 86). Daí exigir-se do Estado comportamento ativo, estando todos os poderes públicos, sem exceção, vinculados a empreender, na esfera de suas respectivas competências, iniciativas concretas em direção à materialização do plano constitucional que tem por fim a superação do ciclo intergeracional de desigualdades e de misérias existente no país.

Nessa linha, uma das principais ferramentas à disposição dos governos para realização de tal tarefa são as políticas públicas. Sem ter a pretensão de adentrar, no âmbito do presente artigo, na complexa discussão acerca da (in)existência de conceito jurídico único do termo "política pública", adota-se, aqui, a definição proposta por Maria Paula Dallari Bucci (2019, p. 816), qual seja: "É a ação governamental coordenada e em escala ampla, atuando sobre problemas complexos, a serviço de uma estratégia determinada, tudo isso conformado por regras e processos jurídicos".

Duas considerações podem ser feitas a partir dessa formulação. Em primeiro lugar, as políticas públicas são consideradas como meio idôneo à realização de toda a ampla gama de objetivos selecionados pela Constituição, o que, por certo, pressupõe a realização de direitos para muito além do que somente aqueles entendidos como fundamentais, apesar da inegável priorização deles. Sem embargo, para o estudo que se propõe neste trabalho, será voltada a atenção para o seu papel na efetivação dos direitos fundamentais, sobretudo os direitos sociais, representantes da segunda geração. 
Isso se justifica pelo fato de que tais direitos têm papel fundamental no objetivo da eliminação da pobreza. Assim, levando em conta que, tratando-se de problema multidimensional, para existir uma política de combate eficiente, é fundamental a intervenção do Estado, por meio de programas sociais amplos que contemplem e possibilitem a elevação do nível de vida das camadas sociais mais pobres, seja pela transferência direta de recursos (v. g., programas de bolsas assistenciais, como o Bolsa Família e o Programa de Erradicação de Trabalho Infantil), ou pelo oferecimento de bons serviços públicos universais de alimentação, moradia, saúde e educação a serem distribuídos equitativamente na sociedade (v. g., Fundo de Combate e Erradicação da Pobreza, que combina transferência de renda com o suplemento de ações de proteção social).

Outra consideração a ser feita é o fato de que a implementação das políticas públicas constitui-se em um processo que se desenvolve por meio de uma sequência de etapas distintas e correlatas, que vão desde a identificação dos problemas que exigem a intervenção estatal, com a definição de estratégias de atuação e deliberações orçamentárias, até a prestação efetiva do serviço essencial, sendo que todas as decisões tomadas nesse ínterim só gozam de legitimação material na medida em que estão de acordo e procuram atender os fins estabelecidos constitucionalmente.

A partir desse cenário, e considerando o processo decisório no ciclo das políticas públicas, assume especial relevância a formulação de uma política tributária, isto é, o complexo de decisões político-legislativas que envolvem os meios pelos quais a arrecadação tributária se dará, observados os limites constitucionais. Assim, a política tributária pode variar entre a alteração de determinada alíquota, ou até mesmo a instituição de um tributo.

Diante disso, para fazer frente às despesas inerentes à manutenção da estrutura de políticas sociais de transferência de renda e de provisão de bens e serviços públicos essenciais aos cidadãos, o Estado depende de recursos financeiros, que, dentro de um modelo econômico capitalista como o adotado pelo nosso país, são arrecadados, via de regra, pela transferência compulsória de riqueza dos particulares por intermédio da imposição de tributos (RIBEIRO; NUNES; ALMEIDA, 2018, p. 129).

A esse propósito, Hugo Thamir Rodrigues e Marguid Schmidt asseveram:

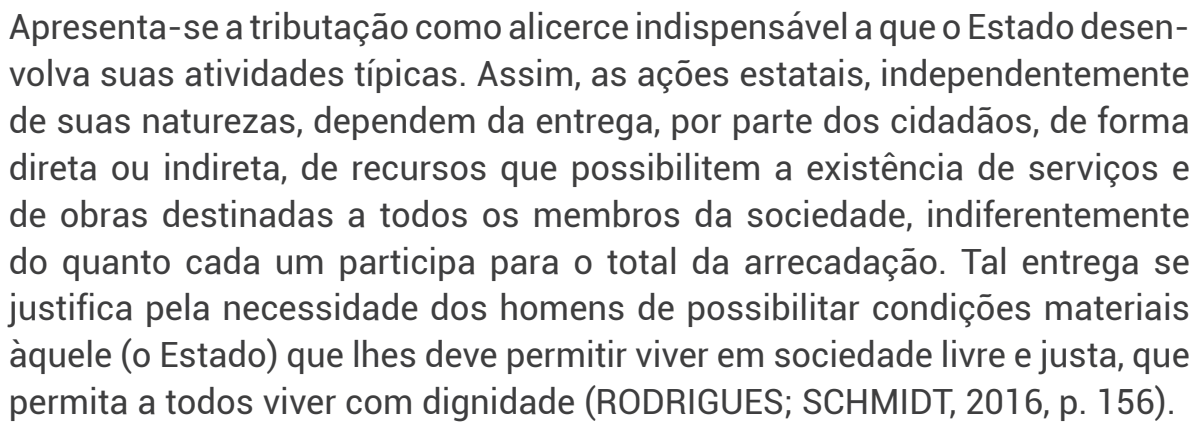

Nada obstante, é certo que o recolhimento de receitas públicas pelo Estado tem como pressuposto inexorável o exercício da atividade legislativa tributária. Isso porque a instituição de tributos pelo Poder Legislativo deve preceder qualquer ato de cobrança, até mesmo porque não pode a administração pública atuar fora do seu âmbito de competência, pretendendo exigir tributo não instituído pelo veículo legislativo pertinente. 
Bem por isso, inclusive, que, ao tratar da competência tributária, entendida justamente como tal prerrogativa do órgão legiferante para criação, por meio de lei, dos tributos a si reservados pelo texto constitucional, Geraldo Ataliba (1998, p. 60) a define como atividade "[...] primária, no sentido de que, sem ela, não pode haver ação tributária (tributação), a qual, como dito, é instrumento indispensável para a satisfação das necessidades públicas".

Nesse contexto, é possível identificar na concretização dos direitos fundamentais uma relação de dependência direta em relação à tributação: sem a instituição de tributos pelo legislador, com a posterior arrecadação de suas receitas pelo administrador público - sobretudo daquelas provenientes dos impostos -, e, portanto, sem o financiamento das ações governamentais, não há meio factível de o Poder Público dar cumprimento adequado à função garantidora que Ihe impôs o próprio texto constitucional, o que acaba por inviabilizar, pois, a satisfação dos objetivos sociais nele resguardados (RIBEIRO; NUNES; ALMEIDA, 2018, p. 129)

Infere-se, com isso, que o legislador, ao lado do administrador público, tem papel fundamental na concretização dos objetivos sociais constitucionalmente definidos, já que toda providência estatal tem seu início no exercício da atividade tributária que lhe compete.

É talvez o que se possa sintetizar com a colocação de Juan F. González Bertomeu, presente no prólogo da obra El costo de los derechos: Por qué la libertad depende de los impuestos, de Stephen Holmes e Cass Sustein (2011, p. 14): "Dime cuántos impuestos te cobran (y cómo se gastan) y te diré qué derechos tienes". Para o autor, levando em conta que a salvaguarda de todo e qualquer direito envolve gasto de dinheiro público, não basta olhar apenas para a Constituição para saber quais direitos são garantidos a uma comunidade, mas, especialmente, para como os recursos se destinam a assegurar seu cumprimento (HOLMES; SUSTEIN, 2011, p. 14), uma vez que de nada adianta a previsão de um direito sem a existência de um aparato estatal capaz de revestir-Ihe de eficácia, pois destituídos de instrumentos de captação financeira bastantes.

Por fim, o caráter dirigente e projetivo da Constituição de 1988 nos assujeita à ideia de que o Estado tem deveres para com a transformação do status quo social e econômico, subordinando toda a atuação deste à concretização dos objetivos que reputa como mais caros à coletividade, em especial aqueles que visam a uma sociedade mais justa e solidária, com a eliminação da pobreza e das desigualdades. Como reflexo de tal propósito, tem-se na garantia dos direitos fundamentais a conformação de um dever jurídico, cujo cumprimento depende precipuamente do exercício pleno da atividade tributária estatal, que abrange não apenas a efetiva cobrança pela Administração Pública, mas, acima de tudo, a própria instituição do tributo pelo Poder Legislativo, a quem foi atribuída a competência tributária.

Feitas tais considerações, passa-se a analisar, no próximo tópico, o instituto do Imposto sobre Grandes Fortunas, cuja importância reside justamente na sua especial vocação para o cumprimento dos principais objetivos estampados no artigo $3^{\circ}$ da Constituição Federal, máxime em razão da vinculação das suas receitas à estruturação do Fundo de Combate e Erradicação da Pobreza, mas que, inexplicavelmente, passados mais de 30 anos da promulgação da Carta Constitucional, ainda não foi instituído, sendo atualmente a única hipótese de não exercício de competência tributária no que se refere aos impostos nominados dentro do ordenamento jurídico brasileiro. 


\section{CONSIDERAÇÓES QUANTO AO IMPOSTO SOBRE GRANDES FORTUNAS E SUA CONTRIBUIÇÃO FRENTE À REALIDADE BRASILEIRA: VINCULAÇÃO AO FUNDO DE COMBATE E ERRADICAÇÁO DA POBREZA}

Inspirado na experiência francesa de tributação de riqueza na década de 1980, com o intitulado Impôt sur les Grandes Fortunes, o Imposto Sobre Grandes Fortunas foi introduzido no Brasil como uma conquista da Assembleia Nacional Constituinte de 1987-88, que, após calorosos debates, logrou êxito em inclui-lo dentre o rol taxativo de impostos de competência da União, mais especificamente no inciso VII do artigo 153 da Constituição Federal (BRASIL, 1998).

Ao contrário do que ocorreu no sistema tributário francês, no entanto, o Imposto Sobre Grandes Fortunas idealizado pelo constituinte nacional nunca chegou a sair do papel, tendo em vista que a eficácia da norma que o estabelece depende, desde 1988, de regulamentação por lei complementar, sendo assim a única ocasião de não exercício da competência tributária da União.

No decorrer dos anos, várias foram as tentativas de regulamentação do imposto, tendo sido levados diversos projetos de lei complementar para exame pelo Congresso Nacional, muitos dos quais sequer foram analisados até os dias de hoje. Ainda assim, não cessaram os esforços na busca por uma norma regulamentadora do IGF, dentre os quais destaca-se o PLS n³15/2015, de iniciativa do senador Paulo Paim, e o PLP n 183/2019, sob autoria de do senador Plínio Valério, ambos em trâmite na Comissão de Assuntos Econômicos do Senado Federal. Também merece destaque o PLP n 50/2020, da senadora Eliziane Gama, como um dos projetos recentemente apresentados em resposta à crise econômica provocada pela eclosão da pandemia do coronavírus, em 2020, que reacendeu a discussão acerca da necessidade da criação do Imposto sobre Grandes Fortunas como fonte de financiamento das necessidades de proteção social.

O importante de se notar em todas essas propostas é que, apesar de apresentarem variações quanto a determinados aspectos (v. g., limite de isenção, percentual da alíquota de incidência, fato gerador etc.), todas compartilham de uma mesma justificativa para a instituição do imposto, qual seja, o combate às vicissitudes do alarmante quadro de desigualdade e de extrema pobreza do país, que, inclusive, já era assolador muito antes de qualquer crise pandêmica, mas que, evidentemente, em face desta, tende a se agravar ainda mais.

De fato, o Imposto sobre Grandes Fortunas tem plena vocação para intervir positivamente sobre tal realidade. Isso se deve principalmente ao fato de que, ao incidir de maneira específica apenas sobre as grandes fortunas ${ }^{4}$, a instituição dessa exação oneraria somente aos detentores das mais expressivas riquezas, o que, por si só, já seria um diferencial benéfico para o arcabouço tributário, marcado pela regressividade.

4 Não existe uma definição pelo constituinte originário do que seja grande fortuna, competindo ao legislador infraconstitucional delimitar o termo, e, portanto, definir qual a faixa de tributação quando da edição da lei complementar regulamentadora. De qualquer forma, indiscutível que a expressão "grandes fortunas" restringe sobremaneira o campo de tributação. 
O sistema tributário brasileiro foi estruturado pouco antes da ascensão da agenda neoliberal no país, que, buscando romper com os paradigmas de ordem social do Welfare State em suas modalidades mais avançadas (SCHMIDT, 2018, p. 121), obstruiu uma agenda de progressividade fiscal. Despertou-se, assim, uma lógica de acumulação de capital a qualquer custo, deixando de lado, com isso, a questão social como uma prioridade, dando espaço para que a sobreposição do capital paulatinamente viesse a conformar um Estado impotente no que diz respeito à implementação de políticas desenvolvimentistas e de proteção social (RODRIGUES; SCHMIDT, 2016, p. 169), as quais ficaram restritas às suas sobras financeiras e orçamentárias (SIQUEIRA; PETRIS, 2017, p. 190).

Apesar da "pretensa neutralidade financeira propugnada pelos liberais" (RODRIGUES; SCHMIDT, 2016, p. 5-6), pode se observar, a partir da década de 1970, uma redução acentuada das alíquotas fiscais incidentes sobre as heranças, doações e ativos financeiros e não financeiros em geral, e, em contrapartida, a estruturação de um sistema de tributação no qual os impostos indiretos representam mais da metade da arrecadação de receita total (OLIVEIRA; BIASOTO JÚNIOR, 2015, p. 5).

Evidentemente, não há nada de ilegal nesse formato de sistema, mas, inserido dentro de um Estado constitucionalmente condicionado a travar uma luta séria contra a pobreza e a desigualdade, e em um país que conta com níveis de concentração excessivamente altos - até mesmo quando em comparação com outros países em desenvolvimento e os Estados Unidos $^{5}$-, ele se revela no mínimo problemático, já que a majoritária parcela dos impostos toma como referência não a renda do contribuinte, mas o consumo, não diferenciando, portanto, os diferentes níveis de poder aquisitivo, o que acaba fazendo com que as camadas sociais mais socialmente fragilizadas paguem proporcionalmente mais tributos do que as mais privilegiadas (OLIVEIRA; BIASOTO JÚNIOR, 2015, p. 12).

Nesse sentido, o já mencionado estudo da Oxfam Brasil, realizado no ano de 2017, constatou que os $10 \%$ com menor renda no Brasil gastam $32 \%$ desta em tributos, $28 \%$ dos quais são indiretos. Por outro lado, os $10 \%$ mais ricos gastam apenas $21 \%$ de sua renda em tributos, sendo apenas $10 \%$ dela destinados ao pagamento de tributos indiretos (OXFAM BRASIL, 2017, p. 48). A discrepância fica sobressaltada, ainda mais ao se considerar que, no ano de 2018, a tributação sobre o consumo representou 44\% da arrecadação do país (BRASIL, 2020, p. 18).

Assim, é inegável, pois, que tal modelo de tributação, em vigor até os dias de hoje, favorece a retroalimentação do fenômeno concentratório e da pobreza, já que, ao mesmo tempo em que estabelece entraves para a ascensão dos segmentos sociais menos favorecidos, possibilita que os detentores de grandes riquezas utilizem do desafogo do seu ônus tributário para conservar e lapidar cada vez mais seu status econômico e social.

Diante de tal cenário, destaca-se a importância do Imposto Sobre Grandes Fortunas, uma vez que a exação não só aliviaria a sobrecarga da tributação sobre o consumo e o serviço, que, como visto, penitencia sobretudo a população menos favorecida economicamente, assim como, também, por se tratar de imposto progressivo, seria apto a realizar, de forma

5 Esses são os resultados de pesquisa desenvolvida por Marc Morgan Milá, que, sob supervisão do prestigiado economista francês Thomas Piketty, verificou que o país vem apresentando uma evolução estável de desigualdade, sendo que as poucas mudanças observadas desde a década de 1970 não figuram de forma alguma como motivo para celebração de qualquer "história de sucesso" do país no combate às disparidades econômicas e sociais (MILÁ, 2015, p. 18, 93). 
especial, o princípio da capacidade contributiva. Tal princípio é vertente do princípio da isonomia material, sendo a relação entre eles ilustrada por Claudiane Aquino Roesel e Maria Flávia de Freitas Ferreira da seguinte forma:

Os princípios da isonomia e da capacidade contributiva se relacionam na medida em que observam a capacidade econômica de cada contribuinte e os tratam de forma igualitária, respeitando a individualidade de cada indivíduo em arcar com o ônus da carga tributária (ROESEL; FERREIRA, 2017, p. 201).

Nada obstante, o IGF vai além, uma vez que carrega consigo ainda outro atributo que o faz se destacar dentre os mecanismos de intervenção articulados em função do combate à pobreza e da redistribuição de renda. Refere-se, aqui, à particularidade de as receitas provenientes da sua arrecadação serem destinadas à implementação de política pública especificamente voltada à promoção de serviços essenciais aos mais necessitados, a fim de lhes conceder as condições básicas necessárias para a superação da pobreza.

Tal vinculação, inegavelmente, não configura mera opção. É, em verdade, uma exigência da própria Constituição Federal, na medida em que esta, excepcionando o postulado da não afetação da espécie tributária (art. 167, IV, CF), vincula expressamente o produto da arrecadação do IGF ao financiamento do chamado Fundo de Combate e Erradicação da Pobreza, conforme art. 80, inciso III, do Ato das Disposições Constitucionais Transitórias (BRASIL, 1988). Senão, vejamos.

O Fundo de Combate e Erradicação da Pobreza (FCEP) foi inaugurado pela Emenda Constitucional $n^{\circ} 31$, de 2000 , tendo como objetivo viabilizar a todos os brasileiros acesso a níveis dignos de subsistência. Tal foi a sua contribuição que, originalmente instituído para vigorar até o ano de 2010, o Congresso entendeu por bem prorrogar seu prazo de vigência por tempo indeterminado, pela aprovação da Emenda Constitucional $n^{a}$ 67, de 2010. Na ocasião, o senador Antônio Carlos Magalhães Junior declarou que tal decisão teve como alicerce o fato de o fundo ter se mostrado essencial para que a questão da superação dos vexatórios indicadores sociais do país fosse colocada no centro do debate político brasileiro (GUERREIRO, 2020).

Como fundo de natureza contábil, sua função é recolher, movimentar e controlar receitas orçamentárias e sua distribuição para atendimento de finalidade específica (SALVADOR; TEIXEIRA, 2014, p. 17), qual seja, a de subsidiar ações suplementares de nutrição, habitação, educação, saúde, reforço de renda familiar e outros programas de interesse social voltados para a melhoria na qualidade de vida, nos termos do que dispõe no art. 79 do ADCT. Vê-se que é da sua própria natureza, portanto, contribuir para o propósito constitucional de eliminação da pobreza, assegurando meios de financiamento para garantia dos direitos-deveres sociais reconhecidos pela Constituição de 1988 e dispensando-os em forma de incentivos financeiros e serviços públicos básicos para o desenvolvimento digno dos cidadãos.

A principal forma pela qual um fundo público capta os recursos necessários para a sua própria estruturação e desempenho de funções é, assim como toda política pública, por meio da arrecadação de recursos de cidadãos com capacidade financeira suficiente para contribuir sem prejudicar sua própria subsistência, o que se dá pela instituição de impostos, contribuições e taxas (SALVADOR; TEIXEIRA, 2014, p. 17). No caso específico do Fundo de Combate e Erradicação da Pobreza, seu principal meio de financiamento, como foi dito, é o Imposto 
Sobre Grandes Fortunas, sendo integrado pela totalidade de suas receitas, razão pela qual, inclusive, adequa-se perfeitamente, dentro da tipologia de Theodore L. Lowi, à categoria de políticas públicas redistributivas, tendo em vista sua inegável repercussão intersetorial, com a necessidade de oferta de serviços para determinado grupo social amplo, os socialmente mais fragilizados, impactando a esfera de interesses do outro grupo de indivíduos igualmente amplo, os privilegiados (LOWI, 1964, p. 691).

Outrossim, apesar do destaque dado ao Imposto Sobre Grandes Fortunas, não se olvida haverem sido previstas outras fontes de custeio para o fundo. Assim, além do IGF, financiam o Fundo de Combate e Erradicação da Pobreza a CPFM, contribuição provisória já extinta, e o adicional de $5 \%$ do Imposto sobre Produtos Industrializados incidente sobre produtos supérfluos, sem prejuízo de eventuais doações e dotações orçamentárias, além de outras receitas a serem definidas na regulamentação do Fundo, consoante art. 80 do ADCT (BRASIL, 1988).

Entretanto, fato é que a inexistência do IGF reduz significativamente a pujança do seu financiamento. Isso ocorre devido ao significativo potencial arrecadatório do imposto, em especial quando se considera que este tem como própria razão de ser o recolhimento periódico de elevados numerários.

Para elucidar tal ideia, estudos do economista Amir Khair (2008, apud ELOI; LOPES, 2016 , p. 121) concluíram que, tendo por base uma alíquota de $1 \%$, poder-se-ia ter arrecadado pela exação do IGF cerca de R\$ 18,5 bilhões, em 1999, e R\$ 22,3 bilhões, em 2000, o que corresponde a $1,73 \%$ e $1,89 \%$ do PIB à época, respectivamente. Mais recentemente, algumas entidades, como a Associação Nacional dos Auditores Fiscais da Receita Federal no Brasil (Anfip) e a Federação Nacional do Fisco Estadual e Distrital (Fenafisco), apresentaram manifesto por meio do qual, dentre outras medidas para enfrentamento da crise ocasionada pela pandemia, propunham a criação do IGF de forma permanente, estimando-se que, com alíquotas progressivas em até $3 \%$ e incidindo sobre patrimônios líquidos superiores a $R \$ 20$ milhões, o que alcançaria tão somente $0,1 \%$ dos contribuintes, lograr-se-ia obter um potencial impressionante, de aproximadamente $\mathrm{R} \$ 40$ bilhões ao ano (SENADO FEDERAL, 2020).

Ademais, como exemplo de uma experiência exitosa concreta, pode se mencionar os dados da França, onde chegou a representar 1,5\% das receitas do governo federal, em 2010, a arrecadação pela taxação da riqueza que inspirou a própria criação do imposto brasileiro em exame (CARVALHO JÚNIOR, 2011, p. 34). Na mesma linha, também tem sido bem-sucedida a tributação de grandes fortunas na Argentina, constatando-se, entre os anos de 2014 e 2017, um crescimento ininterrupto na arrecadação do chamado Impuesto sobre los Bienes Personales (ARGENTINA, 2020) .

Não há dúvidas, portanto, que, ao criar o Fundo de Combate e Erradicação da Pobreza, o constituinte contava com a instituição do Imposto Sobre Grandes Fortunas para dar-Ihe o aporte necessário, até porque estão longe de ser irrisórios os gastos para com um projeto de eliminação da pobreza em um país tido como um dos piores do mundo em matéria de desigualdade de renda e no qual, poucos anos atrás, atestou-se contar com mais de 16 milhões de pessoas vivendo em condições de miséria (OXFAM BRASIL, 2017, p. 12). 
Além do mais, é imperioso enfatizar que, como visto no primeiro capítulo do presente artigo, a Constituição brasileira não é neutra, na medida em que considera e se propõe a transformar a realidade na qual é introduzida. Assim, em uma sociedade que conta com 2,5\% das famílias mais ricas do mundo - para dados de 2000 (CARVALHO JÚNIOR, 2011, p. 36) - e, ao mesmo tempo, com instituições de ensino e estabelecimentos de saúde precários e milhares de indivíduos batalhando contra a fome e a falta de moradia adequada, não seria razoável sustentar que sua lei fundante teria determinado a tributação da riqueza excedente como simples acessório para o custeio de política pública voltada à erradicação da pobreza e das desigualdades.

Deveras, o Fundo de Combate e Erradicação da Pobreza depende precipuamente do IGF para se estruturar, sendo que sua ausência certamente causa uma situação de subfinanciamento capaz de pôr em risco a qualidade e real efetividade do programa constitucional de erradicação da pobreza e desigualdades sociais tão caro à nossa Constituição. Como bem assinalam Ilton Garcia da Costa, Henrique Ribeiro Cardoso e José Leite dos Santos Neto (2018, p. 516) nesse mesmo sentido, "the lack of taxation not only violates the Ability-to-Pay Taxation principle, but also fails to raise a large mass of resources that would be extremely useful for the financing of public policies".

Conclui-se, pois, pela indispensabilidade do Imposto sobre Grandes Fortunas na trama do combate à pobreza e às desigualdades do país, não só em razão da sua aptidão para cumprir com o princípio da igualdade e da capacidade contributiva, mas, em especial, por se tratar de instrumento financeiro determinante para o funcionamento do Fundo de Combate e Erradicação da Pobreza, de sorte que a sua não exação acarreta, inevitavelmente, na prestação deficiente da referida política pública, frustrando, assim, o atendimento dos objetivos fundamentais da República da forma como estabelecida pelo constituinte.

No item seguinte, busca-se analisar o atual cenário, para examinar possível omissão inconstitucional do legislador federal ao deixar de instituir o Imposto Sobre Grandes Fortunas, repensando-se, à luz das diretivas projetivas da Constituição e da sua decisão pela vinculação das receitas do referido imposto à despesa específica, a coerência de se ter a facultatividade como atributo intrínseco da competência tributária.

\section{A NÃO REGULAMENTAÇÃO DO IGF COMO POSSÍVEL OMISSÁO INCONSTITUCIONAL: UMA AVALIAÇÃO DA FACULTATIVIDADE COMO ATRIBUTO DA COMPETÊNCIA TRIBUTÁRIA}

Segundo estudo realizado pela Oxfam, o apoio dos brasileiros à ação de governos no combate às desigualdades aumentou no ano de 2019, em comparação com mesma pesquisa realizada pela organização em 2017. No ano em referência, $77 \%$ dos entrevistados concordaram total ou parcialmente com a afirmação de que o governo federal deve aumentar os impostos de pessoas muito ricas para garantir melhor educação, mais saúde e mais moradias para os que precisam, enquanto, em 2017, tal número era de $71 \%$, o que revela um 
perceptível crescimento nesse posicionamento, especialmente dentre aqueles com renda superior a 5 salários mínimos - em geral mais resistentes à tributação, com a porcentagem tendo evoluído de $56 \%$ para $76 \%$ (OXFAM BRASIL, 2019, p. 27-28).

Diante desse cenário, verifica-se que o Imposto Sobre Grandes Fortunas se adequaria perfeitamente aos anseios da população brasileira, em especial pela destinação das suas receitas à promoção, dentre outros direitos fundamentais básicos, de moradia, saúde e educação aos necessitados, o que, para $94 \%$ dos entrevistados na pesquisa mencionada (somando-se as concordâncias totais e parciais), deve ser o destino fiscal por excelência de todos os tributos (OXFAM BRASIL, 2019, p. 29).

Justamente em sentido oposto, no entanto, observa-se que o Poder Legislativo apresenta certa relutância acerca da tributação das grandes fortunas. Em relação aos projetos de lei apresentados a respeito da implementação do IGF, pontuais são as resistências levantadas. Tem-se o argumento de que a tributação de riquezas poderia ocasionar a evasão de capitais para o exterior, além do desestímulo à poupança, à aquisição de patrimônio e aos investimentos no território nacional (CARVALHO JÚNIOR, 2011, p. 10).

Também justificam a defesa no sentido da não tributação pelas dificuldades e pelos altos custos na administração e na fiscalização do referido imposto, pelo seu baixo potencial arrecadatório, pela pluritributação por ele gerada, e, especialmente, em razão do abandono da tributação das grandes fortunas por diversos países que o adotaram (ELOI; LOPES, 2016, p. 115-116), como, por exemplo, a Áustria, a Dinamarca e a Finlândia (CARVALHO JÚNIOR, 2011, p. 15). Arrimam-se, ainda, em estudos que demonstram que países que tributam o capital não constataram queda significativa da desigualdade social, como no caso da Alemanha e da Suécia (BUFFON; ANSELMINI, 2017, p. 4).

Ocorre que há muito se evidenciou a inconsistência de tais argumentos, ou, ao menos, que os obstáculos apontados não seriam incontornáveis, não fosse a falta de vontade política dos parlamentares. Quanto à evasão, há autores, como Ristea e Trandafir (2010, apud CARVALHO JÚNIOR, 2011, p. 15), que de fato apontam como um dos principais motivos pelo qual os países europeus abandonaram a taxação das grandes fortunas a partir da década de 1990 o fato de o imposto ocasionar transferência de capital a países com menor carga fiscal. Como exemplo, citam a experiência holandesa, em que a extinção do imposto resultou da constatação de seu efeito prejudicial sobre a atividade econômica do país, uma vez que estaria ocasionando a saída do capital produtivo e desencorajando a entrada de investidores estrangeiros (RISTEA; TRANDAFIR, 2010, p. 304).

Entretanto, não se pode olvidar que, atualmente, têm-se evoluído cada vez mais os mecanismos de cruzamento e de rastreabilidade de cadastros, de dados e de informações tributárias (ELOI; LOPES, 2016, p. 121). No contexto brasileiro, há, ainda, a possibilidade de se comparar a declaração do Imposto de Renda com a do IGF, a fim de se detectar eventuais discrepâncias indicadoras de eventuais condutas evasivas (ELOI; LOPES, 2016, p. 122). Ademais, o Brasil é signatário da Norma de Comunicação Comum (CRS), redigida pela Organização para Cooperação e Desenvolvimento (OCDE), que tem por objetivo a comunicação acerca de contas financeiras em escala global. Assim, a Receita Federal, um dos órgãos mais bem estruturados do país, teria ferramentas para combater a possível evasão fiscal que a implementação do IGF possa provocar. 
Outro fator a ser considerado é que o número reduzido de contribuintes do potencial IGF implicaria na maior efetividade da fiscalização, já que o fisco não precisaria criar um sistema que abrange a maior parte da população brasileira, mas a menor parte dela (ELOI; LOPES, 2016 , p. 121). A respeito do argumento de pluritributação, não há nenhum conflito com os impostos existentes, uma vez que a base de cálculo é o valor total dos bens, em um aspecto universal (CAPELEIRO; SILVA, 2019, p. 1440). De qualquer maneira, para os que entendem de forma diversa, alguns dos próprios projetos de instituição do IGF preveem a possibilidade de compensação, a fim de se garantir o princípio do non bis in idem.

O potencial arrecadatório do IGF no Brasil é, ainda, extremamente significativo, conforme o já citado estudo de Amir Khair (ELOI; LOPES, 2016, p. 121). Não se ignora pesquisas que demonstram que, em certos países, foi constatada uma baixa arrecadação com o imposto, como na Espanha, em que este representou apenas 0,5\% das receitas do governo em 2002, tendo sido extinto em 2008 (CARVALHO JÚNIOR, 2011, p. 16). No entanto, há de se considerar que, naquele país, não existia uma grande estrutura de avaliação de imóveis e de ativos financeiros, bem como havia dispositivo que limitava o lançamento conjunto com o Imposto de Renda ao máximo de $60 \%$ da renda do contribuinte residente no país, além de outras deduções, fatores que impactaram diretamente na arrecadação (CARVALHO JÚNIOR, 2011, p. 16).

Além disso, muitas das nações que extinguiram o tributo sobre as grandes fortunas, como a Áustria, a Finlândia e a Dinamarca, assim o fizeram por apresentar desigualdade em níveis significativamente mais baixos, haja vista terem se utilizado, historicamente, de expressiva tributação sobre a riqueza e sobre a transferência (herança e doações), o que não acontece no Brasil (CARVALHO JÚNIOR, 2011, p. 36). No que tange os estudos que revelam em certos países, como a Alemanha e a Suécia, o não alcance do resultado desejado de diminuição de desigualdade, argumenta-se que tal situação se deu pelo fato de estes países isentarem muitos ativos e os avaliarem por valores cadastrais e não por valores de mercado (BUFFON; ANSELMINI, 2017, p. 8).

A diminuição de investimentos também não deve ser um problema, uma vez que recentes estudos divulgados pela Receita Federal constataram que, no ano de 2017, um total de 28 países da OCDE tinham carga tributária sobre a renda, lucro e ganho de capital superior à do Brasil. Entre esses países figuram a França, a Alemanha, os Estados Unidos, o Reino Unido e a Nova Zelândia (BRASIL, 2020, p. 7), e todos ocuparam, de forma invariável, nos últimos três anos (2018-2020), posição igualmente superior no ranking de países mais confiáveis para o investimento estrangeiro direto, segundo indicador formulado pela empresa norte-americana A.T. Kearney (LAUDICINA; PETERSON, 2020, p. 5).

Diante de tais considerações, coaduna-se com a conclusão de João Pedro Schmidt (2018, p. 124), segundo o qual a verdadeira motivação por trás da não instituição do IGF reside, em verdade, no fato de que os possíveis contribuintes, titulares de grandes fortunas, têm grande influência sobre políticas públicas cuja temática é a renda? . Assim, no Brasil, há um manifesto interesse por parte do corpo político na manutenção do status quo tributário, seja para evitar que eles próprios sejam chamados a dispor de parcela da sua riqueza,

7 Nessa linha, cf. COSTA; CARDOSO; SANTOS NETO, 2018, p. 516: "The reasons seem to be obvious: this is not only an economic matter over the risk of capital flight, but it is also a political choice since among the 513 congressmen elected to the 2014-2018 legislature, almost half of them are millionaire, an increasing ratio in each legislature". 
seja para agraciar os interesses da classe elitista do país, sobretudo por sujeitar-se às suas generosas contribuições para o financiamento de campanhas políticas e eleitorais.

Dessa forma, o processo decisório político acaba por representar a vontade de segmento social minoritário favorecido em detrimento do interesse comum da população brasileira, agarrando-se a críticas ultrapassadas para retardar, em prol de uma ambição própria, a regulamentação de um imposto (ELOI; LOPES, 2016, p. 118) que poderia trazer benefícios para toda a sociedade.

A constatação de tal desvirtuamento político esbarra, contudo, na facultatividade como atributo do exercício da competência tributária. Tido como paradigma fundamental da doutrina publicística brasileira, esse elemento faz com que a criação de um tributo seja vista como nada mais que uma decisão política discricionária do ente tributante, permitindo-se ao legislador, portanto, optar por instituir ou não um imposto previsto constitucionalmente, segundo seu próprio juízo de oportunidade e conveniência.

André Luiz Borges Netto (1999, p. 79-80), referendando tal ideia, afirma que as pessoas políticas são livres para utilizarem ou não das regras de competência previstas na Constituição Federal, de modo que sua atuação é sempre facultativa, atentando-se aos princípios da separação dos poderes e da discricionariedade do legislador. Roque Antonio Carazza (2013, p. 766-767) vai mais além, afirmando que, para tomar uma decisão estritamente política, como é a de criar, de não criar ou de criar parcialmente o tributo, a pessoa jurídica de direito público interno não está sujeita a nenhum controle externo.

Assim, verifica-se tratar de concepção oportuna para que se façam prevalecer as preferências políticas sobre as bases constitucionais vigentes. Por esse prisma, o legislador pode utilizar-se do seu poder de discrição e de argumentações subjetivas como subterfúgio para mascarar o seu interesse particular na não tributação das riquezas da classe dominante, sem que se possa, a princípio, taxar sua conduta como contrária ao direito.

É claro que, dentro dessa perspectiva, o menor risco de deixar decisões tão caras à sociedade à mercê de jogos político-partidários já se afigura como fundamento razoavelmente suficiente para se pensar na revisão desse dogma da atividade legislativa tributária. Não obstante, o que se busca demonstrar neste estudo é que, mesmo quando a opção do legislador se pautar em fundamentos legítimos, a ideia da facultatividade como traço da competência tributária não é compatível com os ditames da Constituição.

Pelas palavras de João Almeida de Barros Lima Filho, a atribuição constitucional de competência tributária: "como não poderia deixar de ser, só se compreende à luz de uma interpretação teleológica e sistemática, exigindo o conhecimento não só das prerrogativas estatais, mas também das responsabilidades em razão das quais tais prerrogativas foram instituídas" (2003, p. 116). Isso se deve, sem dúvidas, ao caráter diretivo adotado pela Constituição vigente, que, como visto, pressupõe a irradiação de seus objetivos e fins sobre toda atuação estatal, inclusive a financeira.

Remete-se, aqui, ao exposto no primeiro capítulo do presente trabalho. Destarte, a partir de 1988, a função estatal passou a estar vinculada à atuação com direcionamento total aos esforços de consecução dos desígnios constitucionais (LUCENA, 2017, p. 189). 0 arrolamento de objetivos fundamentais, no art. $3^{\circ}$ da Carta Magna, demonstra o engajamento constitucional em busca de resultados materiais transformadores, tais quais a eliminação da 
pobreza e da marginalização e a redução das desigualdades. E, mesmo quando não ligadas a prestações sociais positivas, mas sobretudo quando assim estão, tais metas reclamam do ente estatal um dever de agir, e não de abster-se, manejando todos os poderes instrumentais à sua disposição para assegurar seu devido alcance.

Frente a esse cenário, constata-se que a Constituição retira o exercício da competência tributária da esfera de discricionariedade do legislador, pois na medida em que toda e qualquer providência estatal exige o dispêndio de recursos orçamentários pelo governo, este não poderia abrir mão do seu principal instrumento de abastecimento dos cofres públicos.

Sem a tributação, o Estado não suportaria as despesas inerentes à realização de suas políticas públicas e acabaria por tolher, assim, qualquer possibilidade de cumprir adequadamente com a imensidão de tarefas a si acometidas, tornando as garantias constitucionais vazias nesse sentido.

Desse modo, não há como se pensar que a Constituição atribuiria aos Poderes Constituídos uma gama de deveres, mas deixaria ao seu alvitre empreender ou não a principal providência para o seu cumprimento. Tal concepção coloca em xeque a própria força normativa do texto constitucional, pois estar-se-ia admitindo que a inércia dos agentes estatais pudesse embaraçar a efetividade de seus mais valiosos enunciados. Partindo dessa mesma ideia, vale lembrar ainda outra lição de João Almeida de Barros Lima Filho:

Entender a instituição de tributos como mera faculdade, seria, de certo modo, qualificar também como faculdade todas as outras atribuições do Estado, já que estas dependem da implementação daquela, o que simplesmente joga por terra um dos fundamentos do Estado de Direito, qual seja, a ideia de que o Estado possui deveres para com os cidadãos, dando-lhes o ensejo de exigir do Estado a satisfação de seus direitos subjetivos (LIMA FILHO, 2003, p. 115).

Se é pacífico, portanto, o entendimento de que o Estado está adstrito a realizar os objetivos sociais constitucionalmente consagrados, não deve ser outro o entendimento senão o de que há, para os entes federativos, um dever de legislar, no sentido de implementação dos tributos arrolados.

Isso fica ainda mais claro quando se discute a não instituição do Imposto sobre Grandes Fortunas, tendo em vista que o não exercício da competência tributária, nesse caso, tem impacto direto no funcionamento do Fundo de Combate e Erradicação da Pobreza. Isso porque, como já evidenciado, a ausência da destinação dos recursos da exação acaba por redundar em uma baixa significativa no financiamento da política pública em questão e, uma vez comprometido o fundo, ficam também comprometidas as ações suplementares de nutrição, habitação, saúde e outras pelas quais aquele se responsabilizou a subsidiar.

Acontece que, seguindo o mesmo raciocínio anteriormente adotado, pelo qual não se pode dissociar a reflexão acerca da obrigatoriedade ou não na instituição de tributos da análise dos fundamentos da função estatal, evidencia-se que a Constituição Federal não autoriza que o Estado assuma um papel neutro na luta contra as desigualdades econômicas e sociais (DIFINI; JOBIM, 2019, p. 284). Dessa forma, uma vez que deixa de atuar positivamente em direção à garantia de serviços sociais básicos, desprezando a exação de imposto indispensável para realização de políticas públicas aptas a realizá-los, o legislador está seguramente 
violando o ordenamento jurídico constitucional. Daí falar-se, então, na inconstitucionalidade por omissão do órgão legiferante.

Decerto, portanto, que a instituição do IGF não pode ser entendida como uma mera opção da pessoa política, uma vez que tal decisão já foi previamente tomada pelo constituinte originário (LIMA FILHO, 2003, p. 90). Tal determinação, inclusive, veio expressa no texto constitucional. Ora, ao vincular o produto da arrecadação do imposto ao custeio do Fundo de Combate e Erradicação da Pobreza, o que se extrai é, em verdade, uma ordem explícita da Constituição para que o legislador exerça a atividade tributária legislativa, dada a sua imprescindibilidade para que o Estado logre cumprir com as suas demais atribuições de promoção de direitos fundamentais, mencionadas categoricamente, inclusive, no próprio art. 79 do ADCT, artigo instituidor do fundo.

Assim, a falta de sua implementação, por meio de lei complementar, constitui afronta à expresso mandamento constitucional - este que, aliás, pode ser extraído não apenas da análise sistêmica de toda a Constituição, mas como também de normas positivadas específicas, dentre as quais destaca-se o art. 145 da CF, que expressa o poder-dever ${ }^{8}$ do Estado na instituição dos tributos em geral, e o art. 80, III, do ADCT, o qual determina a necessidade de destinação das receitas do IGF ao Fundo de Combate e Erradicação da Pobreza. Maurício Barros (2013, p. 123-124) resume tal questão pelo texto que se segue:

Por tudo isso, não cabe considerar a competência tributária como algo facultativo, pois dela depende a efetivação de direitos fundamentais, inclusive os direitos sociais individuais (mínimo existencial). Confirmam essa assertiva os objetivos fundamentais da República elencados no art. $3^{\circ}$ da $\mathrm{CF} / 88$, que impõem dever constitucional implícito para que o Estado esgote suas fontes de receita, de acordo com o primado da justiça fiscal e com a capacidade contributiva dos cidadãos. Por conta disso é inconstitucional a postura omissiva da União Federal ao deixar de exercer a competência tributária enunciada no art. 153, inciso VII, da CF/88, que lhe atribui a competência de instituir o imposto sobre grandes fortunas (IGF), por intermédio de lei complementar. Essa assertiva não decorre de qualquer postura lógica do autor, mas de decorrência de tudo o quanto demonstrado nesse tópico, com o agravante de que o IGF, conforme determina o art. 80 do ADCT (inserido pela Emenda Constitucional 31/2000), deve ter o produto de sua arrecadação afetado ao Fundo de Combate e Erradicação da Pobreza, fundo esse destinado a financiar políticas públicas inerentes à proteção do mínimo existencial [...] (BARROS, 2013, p. 123-124).

Desse modo, evidencia-se uma omissão inconstitucional do ente federativo, que, como bem assevera José Afonso da Silva, resta caracterizada "nos casos em que não sejam praticados os atos legislativos ou administrativos requeridos para tornar plenamente aplicáveis normas constitucionais" (2014, p. 49). Sobre o mesmo assunto, assinala Paulo Eduardo Garrido Modesto que a inconstitucionalidade por omissão se constitui nas situações em que não seja mais razoável "a inércia ou o apelo à discrição política do Poder omisso, isto é, quando não for possível mais aceitar escusa à edição de norma regulamentadora ou execução de medida faltante baseada no juízo de oportunidade e conveniência" (2011, p. 1209), sendo este exatamente o caso da ausência da tributação das grandes riquezas.

8 Cf. LIMA FILHO, 2003, p. 110: "o verbo poder quando dirigido aos entes estatais, não quer dizer faculdade a eles atribuída, senão deveres em razão dos quais os poderes Ihes foram conferidos. Assim, a competência tributária legislativa é um poder e um dever dos entes autônomos do Estado". 
Diante de tal cenário, exsurge a necessidade de reinvindicação da implementação do Imposto Sobre Grandes Fortunas, que já tarda a ser inserida com mais solidez na pauta dos debates jurídicos. Há uma lacuna no sistema tributário brasileiro que deve ser sanada, sob o risco de ser ceifada qualquer chance de algum dia se atingir adequadamente os propósitos que a Constituição se propõe a realizar.

Por parte dos parlamentares, cumpre finalmente dar andamento aos diversos projetos de lei que se propõem a regulamentar o IGF. Propostas como o PLP n 183/2019 do senador Plínio Valério, se aprovadas, seriam de grande valia para a tão ansiada transformação no retrato das desigualdades sociais e econômicas do país. Menciona-se aquele projeto em específico em razão de ser tido, atualmente, como um dos mais exequíveis, em virtude do recente progresso em seu andamento no Senado Federal, dado que as necessidades de reforço financeiro provocadas pela pandemia reacenderam a discussão acerca da taxação de riquezas (CONSELHO NACIONAL DA SAÚDE, 2020).

0 destaque dado também se justifica pelo fato de que, nos termos da iniciativa apresentada, estimou-se obter uma arrecadação de $\mathrm{R} \$ 70$ a 80 bilhões de reais por ano com a imposição tributária, da qual $50 \%$ seriam destinadas ao Fundo Nacional da Saúde, 25\%, ao Fundo de Amparo ao Trabalhador, e 25\%, ao Fundo de Combate e Erradicação da Pobreza (CONSELHO NACIONAL DA SAÚDE, 2020). Assim, apesar de não respeitar a vinculação total das receitas a este último, tal como determina a Constituição, é uma proposta vantajosa, pois, de qualquer modo, destina o produto da arrecadação do imposto integralmente a fundos tencionados ao subsídio de políticas públicas socialmente relevantes.

Nada obstante, compete precipuamente à Corte Constitucional, na persistência da omissão pelo órgão legiferante, promover a defesa dos comandos normativos constitucionais, dentre os quais a determinação do dever de se exercer a competência tributária. Nesse ponto, vale mencionar que a Constituição de 1988 representou um marco de proteção contra movimentos oportunísticos infraconstitucionais, na medida em que disponibiliza diversas técnicas de controle da atividade legislativa. Valendo-se delas, o Judiciário tem o poder de suprir eventuais déficits na atuação do órgão legiferante que estejam colocando em risco a própria observância do horizonte axiológico da ordem constitucional (CALIENDO, 2013, p. 209).

Assim, diante do descumprimento do mandamento constitucional explícito no sentido de criar-se o Imposto sobre Grandes Fortunas, a questão pode e deve ser levada à análise do Supremo Tribunal Federal, por meio de ações diretas de inconstitucionalidade por omissão. Nessa linha, destaca-se a recente iniciativa do Partido Socialismo e Liberdade (PSOL) que, em 2019, através da ADO n55, postulou que o STF declare a omissão do Congresso Nacional em instituir o IGF. Cumpre salientar o seguinte trecho da petição inicial, em que se justifica a adequação desta espécie de remédio jurídico frente à inobservância do poder-dever do Estado de exercer a competência tributária que lhe cabe:

De acordo com o princípio fundamental do Estado de Direito Republicano, o poder político deve ser exercido para a realização, não de interesses particulares, mas do bem comum do povo (res publica). Segue-se daí que toda competência dos órgãos públicos, em lugar de simples faculdade ou direito subjetivo, representa incontestavelmente um poder-dever. Ao dispor a Constituição da República que o Legislativo são "Poderes da União, independentes e harmônicos entre si" (art. $2^{\circ}$ ), ela reforça o princípio que se acaba de 
lembrar, pois quando os órgãos estatais constitucionalmente dotados de competência exclusiva deixam de exercer esses poderes-deveres, o princípio fundamental do Estado de Direito é gravemente lesado. A garantia judicial específica contra essa grave disfunção estatal é a ação de inconstitucionalidade por omissão [...]. (BRASIL, 2019)

Por fim, e o que de mais valor, cabe à própria população brasileira a função de reivindicar os direitos fundamentais que lhe pertencem, já tendo sido verificado avanço nesse sentido, na medida em que, como reportado no início do presente capítulo, estudos da Oxfam demonstraram uma evolução quanto à conscientização da sociedade sobre a necessidade de uma revisão do caráter regressivo do sistema tributário atual, além do aumento de investimentos governamentais em matérias sociais (OXFAM BRASIL, 2019).

Nos últimos meses, a crise econômica e social ocasionada pela pandemia do coronavírus vem evidenciando e exacerbando cada vez mais as situações de desigualdade social e econômica do país. É claro que o risco de contaminação e a paralisação das atividades dele decorrentes atacam sem distinção, mas a maior parte dos indivíduos infectados será justamente aquela que não tem recursos para fugir de aglomerações, recebendo salário em casa e provendo a despensa com compras online, enquanto a imensa massa de desempregados é composta principalmente da mão de obra mais mal remunerada (NEVES, 2020).

É agora, portanto, mais do que nunca, que o Imposto sobre Grandes Fortunas, com todo o seu vasto potencial de redistribuição e de refreamento das mazelas da pobreza, deve vir à tona como instrumento a favor da sociedade brasileira, competindo ao ente tributante finalmente institui-lo, cumprindo com o seu dever constitucional relativo ao exercício da atividade legislativa tributária.

\section{CONCLUSÃO}

A Constituição Federal de 1988, pelo seu caráter dirigente, foi concebida com inegável propósito transformador. Assim, mais do que um documento meramente simbólico, o texto constitucional ambiciona efetivamente intervir na realidade fática na qual se insere, alterando-a e conformando-a nos moldes do que entende ser necessário para a sua prosperidade.

O Brasil apresenta um dos mais elevados índices de miséria e de concentração de renda ao redor do mundo, cenário que é paulatinamente agravado pelo modelo de tributação adotado pelo seu sistema tributário, pois, na medida em que os valores arrecadados são majoritariamente compostos por impostos sobre o consumo, tende-se a gravar de forma mais dura aqueles segmentos sociais menos favorecidos economicamente. Essa conjuntura é a razão pela qual um dos objetivos fundamentais da Constituição é, justamente, a transformação no retrato de desigualdade e pobreza existentes no país.

Diante de tal contexto, a Carta Magna vincula a atuação estatal, em toda sua extensão, à satisfação dos fins por ela perseguidos. Tem-se, assim, a conformação de um dever normativo, que, inobservado, resulta em uma omissão inconstitucional, apta a ser impugnada por meio de ações jurídicas próprias e reinvindicações populares. 
Ocorre que o Estado, para sua própria manutenção e para realização de suas atividades, depende do dispêndio de receitas públicas. Sobretudo no que tange à promoção de direitos fundamentais sociais, essenciais para o cumprimento do objetivo constitucional de erradicação da pobreza, é imprescindível que se obtenha o financiamento adequado para as políticas públicas aptas a realizá-los.

Desta maneira, sendo a tributação o principal instrumento de arrecadação para os cofres públicos, este não está imune às diretrizes constitucionais. Se a Constituição ordena a atuação positiva de todos os Poderes Constituídos, é certo que ela determina, também, que os tributos sejam implementados, uma vez que, sem eles, não há arrecadação e, sem arrecadação, não há meio fático de a Administração Pública cumprir com suas demais atribuições.

O Imposto sobre Grandes Fortunas, nesse sentido, é um dos tributos de cujo recolhimento dependem diretamente as políticas públicas promocionais de direitos fundamentais sociais, na medida em que há previsão constitucional explícita da vinculação da integralidade de suas receitas ao Fundo de Combate e Erradicação da Pobreza, fundo este que se responsabiliza por subsidiar ações suplementares de habitação, educação, saúde, nutrição, dentre outros programas de distinto interesse social.

Por derradeiro, não há espaço para que o legislador opte pela não instituição do IGF, pois, sob a lógica apresentada, a Constituição não autoriza que a omissão do Estado frustre a concretização dos objetivos fundamentais da República. Assim, apesar de tratada como dogma pela doutrina publicística brasileira, não subsiste a concepção da facultatividade como atributo inerente ao exercício da competência tributária.

Portanto, verifica-se que, ao destinar os recursos provenientes da arrecadação do Imposto sobre Grandes Fortunas para o Fundo de Combate e Erradicação da Pobreza, o texto constitucional impõe que aquele seja implementado. Descumprindo tal mandamento, há flagrante inconstitucionalidade na postura do legislador federal, que já tarda em aprovar a lei complementar necessária para a viabilização do imposto.

Evidenciada a ilegalidade na postura do órgão legiferante, é crucial que se passe a demandar do Estado uma resposta quanto à tal omissão, pressionando-o a dar andamento aos projetos de lei complementar em trâmite e, no caso de este permanecer desprezando imposição constitucional expressa, manejando ações diretas de inconstitucionalidade perante o Supremo Tribunal Federal, para que se exerça o devido controle concentrado sob a atuação do Poder Legislativo.

Dessa forma, a presente pesquisa contribui para a temática do IGF, ao investigar a sua instituição não como uma mera escolha política, e, sim, como dever constitucional. Evidencia-se, assim, a necessidade de se questionar determinados dogmas da doutrina publicística brasileira, que não podem ser reproduzidos em detrimento dos ditames da própria Constituição.

Ademais, a análise do Imposto sobre Grandes Fortunas como um imposto justo e juridicamente necessário é especialmente relevante no cenário atual brasileiro. Diante da crise social e econômica alastrada em razão da pandemia decorrente da Covid-19, o país tornou-se terreno fértil para a discussão acerca da implementação de novas medidas tributárias capazes de refrear as crescentes tendências de miséria e de desigualdade no país. 
Todavia, o presente estudo comportou algumas limitações que merecem ser destacadas. Primeiramente, não há muitos países de igual nível de subdesenvolvimento que adotem, ou que adotaram em algum momento, tal modelo tributário para um parâmetro de comparação mais análogo. Além disso, embora no presente trabalho tenha sido discutida a omissão inconstitucional da não instituição do IGF, cabe ressaltar que a mencionada Ação Direta de Inconstitucionalidade por Omissão (ADO) $\mathrm{n}^{\circ} 55$ do Distrito Federal, proposta pelo Partido Socialismo e Liberdade (PSOL), em outubro de 2019, ainda não foi julgada.

No mais, as pesquisas da temática acerca da relação de vínculo entre o Imposto Sobre Grandes Fortunas e o Fundo de Combate e Erradicação da Pobreza ainda são relativamente escassas. Assim, é urgente que futuras investigações sejam conduzidas nesse sentido, com a finalidade de se discutir possibilidades de socorrer aqueles socialmente fragilizados.

\section{REFERÊNCIAS}

ARGENTINA. Ministerio de Hacienda. Subsecretaria de Politica Tributaria Informe sobre la recaudación tributaria III trimestre de 2019. Buenos Aires. Disponível em: https://www.argentina.gob.ar/sites/default/files/it_iii_2019. pdf. Acesso em: 13 jul. 2020.

ATALIBA, Geraldo. Hipótese de incidência tributária. 5. ed. São Paulo: Malheiros, 1998.

BARCELLOS, Ana Paula de. Neoconstitucionalismo, direitos fundamentais e controle das políticas públicas. Revista de Direito Administrativo, Rio de Janeiro, v. 240, p. 83-103, abr./jun. 2005. Disponível em: http://bibliotecadigital.fgv.br/ojs/index.php/rda/article/view/43620/44697. Acesso em: 20 jun. 2020.

BARROS, Maurício. A efetivação dos direitos sociais por medidas fiscais e financeiras - instrumentos para a superação do subdesenvolvimento. 2013. Tese (Doutorado em Direito Econômico, Financeiro e Tributário) Faculdade de Direito, USP, São Paulo, 2013. Disponível em: https://www.teses.usp.br/teses/disponiveis/2/2133/ tde-02122016-093313/publico/TESE_Mauricio_Barros.pdf. Acesso em: 18 jul. 2020.

BELLO, Enzo; BERCOVICl, Gilberto; LIMA, Martonio Mont'Alverne Barreto. O Fim das Ilusões Constitucionais de 1988?. Revista Direito e Práxis, Rio de Janeiro, v. 10, n. 3, p. 1769-1811, set. 2019. Disponível em: https://www. scielo.br/pdf/rdp/v10n3/2179-8966-rdp-10-03-1769.pdf. Acesso em: 20 jun. 2020.

BORGES NETTO, André Luiz. Competências legislativas dos Estados-membros. 1. ed. São Paulo: Revista dos Tribunais, 1999.

BRASIL. (Constituição 1988). Constituição da República Federativa do Brasil de 1988. Brasília, DF: Presidência da República. Disponível em: http://www.planalto.gov.br/ccivil_03/constituicao/constituicao.htm. Acesso em: 08 jul. 2020.

BRASIL. Receita Federal. Carga Tributária no Brasil - 2018 (Análise por Tributos e Base de Incidência). Brasília, mar. 2020. Disponível em: https://receita.economia.gov.br/dados/receitadata/estudos-e-tributarios-e-aduaneiros/estudos-e-estatisticas/carga-tributaria-no-brasil/ctb-2018-publicacao-v5.pdf. Acesso em: 28 set. 2020.

BRASIL. Supremo Tribunal Federal. Ação direta de inconstitucionalidade $n^{\circ}$ 55/DF. Requerente: Partido Socialismo e Liberdade (P-SOL). Intimado: Congresso Nacional. Relator: Min. Marco Aurélio. Brasília, 2 de outubro de 2019. Disponível em: http://redir.stf.jus.br/estfvisualizadorpub/jsp/consultarprocessoeletronico/ConsultarProcessoEletronico.jsf?seqobjetoincidente=5786819. Acesso em: 23 jul. 2020.

BUCCI, Maria Paula Dallari. Método e aplicações de abordagem direito e políticas públicas (DPP). Revista Estudos Institucionais, Rio de Janeiro, v. 5, n. 3, p. 791-832, set./dez. 2019. Disponível em: https://estudosinstitucionais. com/REl/article/view/430/447. Acesso em: 26 jul. 2020. 
BUFFON, Marciano; ANSELMINI, Priscila. O imposto mundial sobre o capital: da sua relevância sócio-jurídica para a redução da desigualdade de renda e patrimônio, a partir de Piketty. RDIET, Brasília, v. 12, n. 1, p. 1-26, jan./jun. 2017. Disponível em: https://portalrevistas.ucb.br/index.php/RDIET/article/view/8186. Acesso em: 28 set. 2020.

CALIENDO, Paulo. Neoconstitucionalismo e Direito Tributário. Revista da AJURIS, Rio Grande do Sul, v. 40, n. 129, p. 199-223, mar. 2013. Disponível em: http://ajuris.kinghost.net/OJS2/index.php/REVAJURIS/article/ view/313/248. Acesso em: 20 jun. 2020.

CANOTILHO, José Joaquim Gomes. Constituição Dirigente e Vinculação do Legislador: contributo para a Compreensão das Normas Constitucionais Programáticas. 2. ed. Coimbra: Coimbra, 2001.

CARVALHO JÚNIOR, Pedro Humberto Bruno de. As discussões sobre a regulamentação do Imposto Sobre Grandes Fortunas: a situação no Brasil e a experiência internacional. Nota Técnica do IPEA, Rio de Janeiro, p. 1-50, out. 2011. Disponível em: http://repositorio.ipea.gov.br/handle/11058/5755. Acesso em: 10 jun. 2020.

CAPELEIRO, Pedro Igor Evangelista de O.; SILVA, Carlos Sério Gurgel da. Imposto sobre Grandes Fortunas: da sua regulamentação ao necessário contrafluxo da carga tributária indiretamente aplicada sobre o consumo. Revista Jurídica Luso-Brasileira, Lisboa, ano 5, n. 5, p. 1415-1461, 2019. Disponível em: https://www.cidp.pt/revistas/ rjlb/2019/5/2019_05_1415_1461.pdf. Acesso em: 01 out. 2020.

COSTA, Ilton Garcia da; CARDOSO, Henrique Ribeiro; SANTOS NETO, José Leite dos. Can Tax Justice Rearrange An Unfair System? The Brazilian Case. Revista Jurídica, Curitiba, v. 2, n. 51, p. 502-523, 2018. Disponível em: http:// revista.unicuritiba.edu.br/index.php/RevJur/article/viewFile/3084/371371618. Acesso em: 08 jul. 2020.

DIFINI, Luiz Felipe Silveira; JOBIM, Eduardo de Sampaio Leite. Estado fiscal, tributação e os critérios de justiça no direito tributário. Revista da Faculdade de Direito da UFRGS, Porto Alegre, n. 41, p. 278-304, dez. 2019. Disponível em: https://seer.ufrgs.br/revfacdir/article/view/95205. Acesso em: 12 jul. 2020.

ELOI, Pilar de Souza e Paula; LOPES, Yara Almeida. A não regulamentação do IGF e os entraves que o rodeiam: Um estudo sobre o porquê da não normatização dessa espécie tributária. Em tempo, Marília, v. 15, p. 107-129, 2016. Disponível em: http://www.mpsp.mp.br/portal/page/portal/documentacao_e_divulgacao/doc_biblioteca/ bibli_servicos_produtos/bibli_informativo/bibli_inf_2006/Em-Tempo_v.15.06.pdf. Acesso em: 20 maio 2020.

GRAU, Eros Roberto. A ordem econômica na Constituição de 1988. 14. ed. São Paulo: Malheiros, 2010.

GUERREIRO, Gabriela. Senado aprova prorrogação da vigência do Fundo de Combate e Erradicação da Pobreza. Folha de São Paulo, São Paulo, 7 de julho de 2020. Disponível em: https://www1.folha.uol.com.br/poder/763570-senado-aprova-prorrogacao-da-vigencia-do-fundo-de-combate-e-erradicacao-da-pobreza.shtml. Acesso em: 05 jul. 2020.

HESSE, Honrad. A força normativa da Constituição. Tradução: Gilmar Ferreira Mendes. Porto Alegre: Sergio Antonio Fabris, 1991.

HOLMES, Stephen; SUSTEIN, Cass. El costo de los derechos: Por qué la libertad depende de los impuestos. Tradução: Stella Mastrangelo. 1. ed. Buenos Aires: Siglo Veintiuno, 2011.

LAUDICINA, Paul; PETERSON, Erik. The 2020 Kearney Foreign Direct Investment Confidence Index. 16 de junho de 2020. Disponível em: https://www.kearney.com/documents/20152/17744880/The+2020+Kearney+Foreign+D irect+Investment+Confidence+Index.pdf/18e45f29-867f-2cad-1899-8294b94e89d5?t=1592240888756. Acesso em: 01 out. 2020 .

LIMA FILHO, João Almeida de Barro. A distribuição da competência legislativa tributária no Brasil: a obrigatoriedade do seu exercício. 2003. Dissertação (Mestrado em Direito) - UFPE, Recife, 2003. Disponível em: https:// repositorio.ufpe.br/bitstream/123456789/4354/1/arquivo5499_1.pdf. Acesso em: 05 jul. 2020.

LOWI, Theodore J. American Business, Public Policy, Case-Studies and Political Theory. World Politics, Cambridge, v. 16, n. 4, p. 677-715, jul. 1964. Disponível em: https://www.cambridge.org/core/journals/world-politics/article/ american-business-public-policy-case-studies-and-political-ory/6621 C1B577BB52D00AFBD70F82B94C2D. Acesso em: 08 jul. 2020.

LUCENA, Pedro Flávio Cardoso. Competência tributária e facultatividade: conceitos jurídicos logicamente incompatíveis. Revista de Direito Tributário Contemporâneo, São Paulo, v. 9, p. 187-206, nov./dez. 2017. 
MODESTO, Paulo Eduardo Garrido. Inconstitucionalidade por omissão: categoria jurídica e ação constitucional específica. Doutrinas Essenciais de Direito Constitucional, [s. I.], v. 5, p. 1203-1230, maio 2011.

MILÁ, Marc Morgan. Income Concentration in a Context of Late Development: An Investigation of Top Incomes in Brazil using Tax Records, 1993-2013. 2015. Dissertação (Mestrado em Políticas Públicas e Desenvolvimento) - Paris School of Economics, Paris, 2015. Disponível em: http://piketty.pse.ens.fr/files/MorganMila2015.pdf. Acesso em: 03 jul. 2020.

NEVES, Ernesto. A pandemia expõe e agrava as desigualdades sociais no planeta. Veja, Rio de Janeiro, n. 2689, ano 53, n. 23, 29 maio 2020. Disponível em: https://veja.abril.com.br/mundo/a-pandemia-expoe-e-agrava-as-desigualdades-sociais-no-planeta/. Acesso em: 20 jul. 2020.

OLIVEIRA, Fabrício Augusto de; BIASOTO JÚNIOR, Geraldo. A reforma tributária: removendo entraves para o crescimento, a inclusão social e o fortalecimento da federação. Revista Política Social e Desenvolvimento, [s. I.], ano 3, nov. 2015. Disponível em: http://plataformapoliticasocial.com.br/wp-content/uploads/2015/11/revista-pps-25_5-11.pdf. Acesso em: 03 jul. 2020.

OXFAM BRASIL. Relatório "A distância que nos une: um retrato das desigualdades brasileiras", set. 2017. Disponível em: https://www.oxfam.org.br/um-retrato-das-desigualdades-brasileiras/a-distancia-que-nos-une/. Acesso em: 23 jun. 2020.

OXFAM BRASIL. Relatório “Nós e as Desigualdades", jun. 2019. Disponível em: https://www.oxfam.org.br/um-retrato-das-desigualdades-brasileiras/pesquisa-nos-e-as-desigualdades/pesquisa-nos-e-as-desigualdades-2019/?_ga=2.49432036.330511726.1595133669-697185239.1595133669. Acesso em: 14 jul. 2020.

RIBEIRO, Maria de Fátima; NUNES, Geilson; ALMEIDA, Patrícia Silva de. O desenvolvimento dos direitos fundamentais através da tributação: políticas públicas como fomento do bem-estar social. Meritum, Belo Horizonte, v. 13, n. 1, p. 128-146, jan./jun. 2018.

Disponível em: http://www.fumec.br/revistas/meritum/article/view/5827. Acesso em: 26 jul. 2020.

RISTEA, Luminita; TRANDAFIR, Adina. Wealth Tax Within Europe in the Context of a Possible Implementation in Romania: the existing Wealth Tax and its decline in Europe. Annals of the University of Petrosani Economics, Bucareste, v. 10, n 2, p. 299-306, 2010. Disponível em: https://core.ac.uk/download/pdf/25851962.pdf. Acesso em: 29 set. 2020 .

RODRIGUES, Hugo Thamir; SCHMIDT, Marguid. A concretização do princípio da dignidade da pessoa humana como legitimizadora da tributação no Estado Democrático de Direito: solidariedade e neoliberalismo. Revista Jurídica, Curitiba, v. 4, n. 45, p. 154-179, 2016. Disponível em: http://revista.unicuritiba.edu.br/index.php/RevJur/ article/view/1786/1174. Acesso em: 07 jul. 2020.

ROESEL, Claudiane Aquino; FERREIRA, Maria Flávia de Freitas. A tributação como instrumento de justiça social. Meritum, Belo Horizonte, v. 12, n. 1, p. 196-210, jan./jun. 2017. Disponível em: http://www.fumec.br/revistas/ meritum/article/view/5216/pdf. Acesso em: 24 jul. 2020.

SALVADOR, Evilasio; TEIXEIRA, Sandra Oliveira. Orçamento e políticas sociais: metodologia de análise na perspectiva crítica. Revista de Políticas Públicas, São Luís, v. 18, n. 1, p. 15-32, jan./jul. 2014. Disponível em: http:// www.periodicoseletronicos.ufma.br/index.php/rppublica/article/view/2681/700. Acesso em: 06 jul. 2020.

SCHMIDT, João Pedro. Para estudar políticas públicas: aspectos conceituais, metodológicos e abordagens teóricas. Revista do Direito, Santa Cruz do Sul, v. 3, n. 53, p. 119-149, set./dez. 2018. Disponível em: https://online. unisc.br/seer/index.php/direito/article/view/12688. Acesso em: 26 jul. 2020.

SENADO debate quatro propostas de imposto sobre grandes fortunas. Senado Notícias, Brasília, 27 mar. 2020. Disponível em: https://www12.senado.leg.br/noticias/materias/2020/03/27/senado-debate-quatro-propostas-de-imposto-sobre-grandes-fortunas. Acesso em: 08 jul. 2020.

SILVA, José Afonso da. Curso de Direito Constitucional Positivo. 37. ed. São Paulo: Malheiros, 2014. 
SIQUEIRA, Dirceu Pereira; PETRIS, Maria Eduarda Pires. Reserva do possível e os direitos sociais: da previsão normativa a concretização. Revista Jurídica, Curitiba, v. 1, n. 46, p. 188-203, 2017. Disponível em: http://revista. unicuritiba.edu.br/index.php/RevJur/article/view/2045. Acesso em: 26 jul. 2020.

Recebido/Received: 27.07.2020.

Aprovado/Approved: 25.10.2020. 